\title{
Probiotic effect of FLOC on Vibrios in the pacific white shrimp Litopenaeus Vannamei
}

\author{
Diana Aguilera-Rivera ${ }^{\mathrm{a}}$, Alejandra Prieto-Davóc ${ }^{\mathrm{c}}$, Karla Escalante $^{\mathrm{b}}$, Cristina Chávez $^{\mathrm{d}}$, Gerard Cuzon $^{\mathrm{e}}$, \\ Gabriela Gaxiola ${ }^{\mathrm{b}, *}$
}

\author{
${ }^{a}$ Posgrado en Ciencias Del Mar y Limnología, UNAM, México \\ ${ }^{\mathrm{b}}$ UMDI-Sisal, Fac. de Ciencias, UNAM \\ ' Unidad de Quimica-Sisal, Fac. de Química, UNAM, México \\ ${ }^{d}$ CIAD-Unidad Mazatlán, México \\ e COP-Tahití, Ifremer, France
}

*: Corresponding author : Gabriela Gaxiola, email address : $\underline{\text { mggc@ciencias.unam.mx }}$

\begin{abstract}
:
The advantages of FLOC over clear water (CW) in rearing juvenile L. vannamei and its effects on Vibrio communities were evaluated. Survival rate in FLOC and clear water were recorded and a probiotic was tested under both conditions. Daily growth rate (DGR) was higher in FLOC $(p<0.05)$ than in CW. Survival in each system increased significantly when a probiotic was included in the diet $(p<0.05)$. The Vibrionaceae community from the hepatopancreas $(\mathrm{HP})$ and the culture medium did not differ between the two culture media. Nevertheless, a novel group of Vibrio strains was found to be unique to FLOC. No high level of lesions was observed in shrimp tissues from the FLOC + probiotic treatment; it suggests that the probiotic contributed to homeostasis and prevented outbreak of opportunistic pathogenic species.
\end{abstract}

\section{Highlights}

It is described a vibriosis situation in a rearing system for shrimp $>$ Molecular analysis of Vibrios in "floc" for shrimp was conducted Phylogenetic tree for Vibrios in shrimp and seawater is displayed The addition of probiotic in clear water and "floc" conditions are examined Hepatopancreas histopathology showed that shrimp in floc had a better immune status than in clear water

Keywords : FLOC ; Probiotic ; L.vannamei ; Disease ; Vibrio 


\section{Introduction}

BioFLOCs (Avnimelech, 2012) can assimilate pollutants from the water column (Valdes et al, 2013) and provide farmed shrimp with protein during the grow-out period. However, not all Vibrio species present in FLOC are beneficial to shrimp (Juis-Villasenor et al, 2013), and use of FLOC may introduce pathogenic Vibrio species into CW. The question is whether a FLOC medium will be enhanced by introduction of probiotics (Sapcharaen et al., 2013). Cultivation of penaeid shrimp under FLOC conditions started in the early 1970s as a new system to intensify culture (AQUACOP, 1984) and produced healthy animals (Far et al., 2013). FLOC was defined as a medium rich in organic matter, made of particulate biomass and colonized by bacteria. From a nutritional point of view it helps shrimp to gain weight (more than $2 \mathrm{~g}$ per week) owing to an abundance of native protein sources from protozoa, filamentous bacteria, nematodes, ciliates, flagellates, and rotifers (Decamp et al., 2002; Ray et al., 2010). Bacteria in FLOC fluctuate and can have some antibiotic activity and similar genetic composition to that observed in wild life communities (Bianchi, 1979). Bacterial ecology in these systems achieves nutrient equilibrium because nitrogen is recycled and transformed by nitrifying bacteria (Burford, 2004). Natural production of some substances (Dinh et al., 2010; lyapparaj et al., 2013) by bacteria in FLOC (Halet et al., 2007) has been reported to inhibit growth of co-habiting pathogenic species such as $V$. harveyi (Defoirdt et al., 2007). Furthermore, FLOC can improve shrimp gonadal maturity, as shown with females (Emerenciano et al., 2013).

Probiotics can control diseases in ponds (Moriarty, 1999). Also different quality waters affect the bacterial composition of shrimp gut: Moss et al. (2000) found higher diversity of Gramm negative aerobic bacteria in eutrophic media compared 
to an oligotrophic one; Izquierdo et al. (2006) observed better survival and growth of shrimp cultivated green than those form clear water. Pediococcus sp. has been coated on pelleted feed for juveniles L. stylirostris (Castex et al., 2008). These efforts brought in a better control of pathogenic bacterial communities without changing the main physicochemical characteristics of seawater.

The purpose of the present study was to investigate the advantages of using Bio»FLOC» Technology (BFT) over the more traditional CW technique for growing L. vannamei, and to evaluate the effects of a probiotic feed supplement on the Vibrio community.

\section{Materials and methods}

Juvenile shrimp L. vannamei were originally caught from ponds at UMDI Sisal (UNAM) where they were kept in FLOC (Emerenciano et al., 2013) at 40 shrimp per $\mathrm{m}^{2}$, with zero water exchange, heterotrophic media, constant aeration, a commercial pellet feed (35\% od Crude Protein, Malta Cleyton) and organic fertilization with molasses. For the trial 280 shrimp were used and their initial average weight was $4.8 \pm 0.6 \mathrm{~g}$ at nearly $2 \mathrm{~g}$ biomass per $\mathrm{m}^{2}$, Water quality was assessed twice a day (08:00 and 16:00 h.): salinity (Vital Sine ${ }^{\mathrm{TM}}$ model SR6, Apopka, Florida, USA), temperature, dissolved oxygen (DO) (HACH Co. model hqd40, Loveland, Colorado, USA), $\mathrm{pH}$ (pH $\operatorname{Testr}^{\top \mathrm{TM}} 30$, Vernon Hills, Illinois, USA), and ammonium (TAN), nitrates $\left(\mathrm{NO}_{3}{ }^{-}\right)$, and nitrites $\left(\mathrm{NO}_{2}{ }^{-}\right)$with a saltwater master kit (HACH Co., Loveland, Colorado, USA). FLOC volume (FV) was controlled three times per week with an Imhoff cone. Clear water had closed recirculation with a continuous $30 \%$ renewal+aeration. Water quality was maintained through three filters 30, 10 and $5 \mu \mathrm{m}$ mesh, a biological filter (live rock) and a sand filter, and the temperature was set at $28^{\circ} \mathrm{C}$ with a chiller Aquabone $\AA$; water passed through an 
ozonizer lkal-HA ${ }^{\mathrm{TM}}$ model 1000, Cuernavaca, Morelos, Mexico. Meanwhile, the FLOC treatment had closed recirculation from a mesocosm main tank to feed experimental units, with aeration and zero water exchange. The trial lasted 45 days under a 12:12 light-dark photoperiod. The commercial feed was fed to the juveniles at $2 \%$ of body weight. A carbon source (molasses) maintained $\mathrm{C}: \mathrm{N}$ ratio at 20:1 (Avnimelech, 2012). The food was placed on a feeding tray at 08:00, 14:00 and 20:00 h. Remaining food was siphoned out each morning. Every 15 days, the weight gain was measured and the feed was adjusted. A commercial probiotic was added, containing a mixture of Bacillus subtilis, B. natto, $B$. megaterium, Lactobacillus acidophilus, L. plantarum, L. brevis, L. casei and Saccharomyces cerevisiae (Altai ${ }^{\mathrm{TM}}$, Providencia, Santiago, Chile) at $10^{9} \mathrm{CFU} \mathrm{g}^{-1}$ or $2.3 \mathrm{~g} \mathrm{~kg}^{-1}$ feed. Daily growth coefficient (DGC) was expressed as mg day ${ }^{-1}(($ final weight ${ }^{1 / 3}$-initial weight $\left.{ }^{1 / 3}\right) / \mathrm{t}$, days) ${ }^{*} 100$ and survival percentage was calculated as final minus initial number of shrimp* 100 .

Water quality in the tanks was sampled at days $1,15,30$ and 45 . Ten shrimp were taken at day one (control) and on day 45 for each treatment. For histological studies samples of the HP in Davidson solution were processed at the Research Centre for Food and Development (CIAD, A.C in Mazatlán, Sinaloa, Mexico). Samples were dehydrated (Tissue-Tek ${ }^{\mathrm{TM}}$ II model 4640-B, Tokyo, Japan), paraffinembedded (Leica ${ }^{\text {TM }}$ EG1160, Nussloch, Germany) and sliced in a microtome Leica $^{\text {TM }}$ 820, Nussloch, Germany (Lightner, 1996). Sections of the HP were stained with hematoxylin \& eosin for identification of lesions observed with Olympus $^{\mathrm{TM}} \mathrm{CH} 30$, Melville, NY and classified according to $1=$ less severe, $2=$ severe, $3=$ more severe. Tissues with the greatest severity of lesions were sent 
to the APL (U o Arizona) and a fluorescent in situ hybridization (FISH) assay was performed to confirm a Necrotizing Hepatopancreatitis (NHP) disease. FISH assays used paraffin blocks previously prepared for histology, and a gene probe specific to the detection of NHP-causing bacteria; consecutive sections from each block were stained with Mayer-Bennett hematoxylin \& eosin-phloxine.

All bacteria samples were cultured on TCBS agar selective for Vibrio. The colonies were differentiated according to their morphology and isolated for DNA extraction. $\left.\begin{array}{llllll}\text { Primes } & 357 \mathrm{~F} & (5 & \text { 'CCTACGGGAGGCAGCAG } & 3\end{array}\right)$ and $907 \mathrm{R} \quad(5$ 'CCGTCAATTCCTTTGAGTTT 3') corresponding to variable regions V3-V5 were used for 165 ribosomal RNA gene amplification. PCR products were purified and sent for sequencing to the Biotechnology Institute (IBT-UNAM). Sequences were aligned with MUSCLE through the MEGATM 5 interphase along with the $16 S$ ribosomal gene sequences from Vibrio strains identified with the BLAST EzTaxonTM Server 2.1 platform (Chun et al., 2007) as the nearest matches to our sequences. Phylogenetic tree (Fig 1) was constructed on alignments using $470 \mathrm{bp}$. The phylogenetic tree was generated using the Neighbor-Joining statistical method and a Jukes-Cantor substitution model. All trees were validated by a bootstrap method as a support test of their phylogeny. All data were analyzed with the Statistica ${ }^{\mathrm{TM}} 5.0$ bioinformatic program. Bifactorial ANOVA of $2 \times 2$ (CW vs FLOC; and presence/ absence of probiotic) was applied on DGR and survival (previously arcsine-transformed), at significance level 0.05 (Tukey test).

\section{Results}

DGC and survival of shrimp all showed the significant advantage of FLOC over CW (Table 2). 16S ribosomal RNA gene sequences of the representative vibrios showed $>98 \%$ of identity for $V$. rotiferianus, $V$. owensii, $V$. plantisponsor and $V$. 
vulnificus. HP histology allowed a comparison between animals grown in CW or FLOC, and between the presence/absence of a probiotic. Shrimp sampled as a control group on day 1 showed level 1 lesion in HP. Regardless of presence of feed probiotic, at day 45 severe lesions (level 2 and 3) were more common on shrimp in CW than in FLOC (Table 3, Fig 1).

FISH analyses suggested that the level 1 and 2 lesions found in the tissues from shrimp fed probiotics have been a result of "Septic Hepatopancreatitis Necrosis" (SHPN), an infection caused by a pathogenic Vibrio sp. (APL pers. com,). There was no evidence of Candidatus hepatobacter penaei.

\section{Discussion}

The growth results confirmed previous reports related to significant improvement in growth and health of shrimp cultured in FLOC (Emerenciano, 2013). In this study the addition of a probiotic to the diet, whether in $\mathrm{CW}$ or in FLOC, had a beneficial effect on survival. Shrimp grown in CW were significantly smaller $(p>0.05)$, and survival rates lower $(p<0.05)$ than those grown in a FLOC. Furthermore, more shrimp had severe (level 2 and 3) lesions in HP when grown in CW. The type of lesions suggested a disease, SHPN or Vibriosis (Soto-Rodríguez et al., 2010), caused by a Vibrio peneicidae. (Saulnier et al., 2000; Goarant and Merien, 2006) or V. alginolyticus (Hsieh et al., 2007).

Actually, probiotics are extensively used in aquaculture (Vine et al., 2006), and they enhance the growth and survival of shrimp (Supamattaya et al., 2005); this was confirmed in the present study for survival in each rearing medium, and for weight gain in FLOC. Previous observations suggest that the resulting $\mathrm{pH}$ decrease due to transformation of sugars into lactic acid by the Lactobacillus spp. can, at the same time, avoid the proliferation of pathogens (Ma et al., 2009), as 
has been shown for pathogenic Vibrio species in shrimp aquaculture (Griffith, 1995). However, the effect of probiotics on the composition of the Vibrionaceae community in rearing system and shrimp gut has not been established, nor their effects on the severity of the disease. The probiotic altered the species composition of the Vibrio community in a similar way in each rearing system. The relative severity of disease suggests a synergistic effect between the probiotic and FLOC that creates an advantage over CW to prevent a pathogenic outbreak. This could very well explain an increase in average growth and survival rates observed in FLOC tanks where probiotic was added, as well as the low number of severe lesions observed in the shrimp tissues. In addition, FLOC provides shrimp with nutrients (Crab, 2010) and increases their nutrition thanks to molasses (Schneider et al., 2006). Survival rates also improved not only because of a better nutrition (Burford et al., 2004), but also due to a stable bacterial community able to control pathogenic outbreak (Thompson et al., 1999). Furthermore, it has been suggested that FLOC benefits the shrimp immune system (Hsieh et al., 2007), since bacteria isolated from FLOC produced carotenoids, retinoids, poly- $\beta$-hydroxybutyrate (Defoirdt et al., 2007; Nhan et al., 2010) and exoenzymes (Bairagi et aal., 2002). In FLOC, although some shrimp developed severe tissue lesions, caused by bacterial infections, these were fewer than in CW. The exclusiveness of the novel group of vibrios found in FLOC was confirmed during this trial when five more sequences that belonged to isolates recovered from FLOC and to the shrimp obtained from this system claded within it. Among the identified species, $V$. harveyi has been known to cause pathogenic outbreaks (Lightner, 1996) that have highly increased mortalities in shrimp. These outbreaks disturb the equilibrium among the bacterial communities present in the rearing medium, making it easier to cause 
massive infections that will create lesions in shrimp tissues and eventually lead to death. Another explanation for the changes in the Vibrionaceae community is the effect of quorum-sensing molecules. $B$. subtilis present in the probiotic is known to produce communication molecules to alternate between competence for DNA uptake and sporulation (Kumar and Singh, 2013). These molecules could in turn interfere with the communication between vibrios and therefore prevent their proliferation.

This study revealed the presence of a unique group of vibrios exclusively found in FLOC, and shrimp showed better health status than those grown in CW. It suggests not only the strengthening of the shrimp immune system by the molecules described above, but also a structuring of the microbial community that may be keeping in equilibrium and prevent an outbreak from unidentified opportunistic pathogenic Vibrio.

\section{Conclusion}

This study showed a synergistic effect of probiotic and Bio»FLOC» for the juveniles of $L$. vannamei that prevented the progression of lesions in HP caused by pathogenic vibrios present in the water. Bio»FLOC» was initially developed to mitigate the water quality problem that can often related to mortality; it can limit contamination in natural water, thereby preventing a spread of pathogens. Under such conditions of zero water exchange, antibiosis can occur naturally; growth and survival would be similar with probiotic. The differences in vibrio species observed between $\mathrm{CW}$ and FLOC resided in the fact that some microorganisms in FLOC particles play a key role on bacterial communities. Histopathology showed that shrimp in FLOC had better immune status than in CW, where more lesions occurred with or without probiotic; therefore, although probiotic effected on survival 
by stabilizing to some extent the shrimp digestive flora, this was not enough to enhance growth rate. A dose-response should confirm an absence of effect.

\section{Acknowledgements}

This project is financed by CONACYT (Project No.167670). We appreciate the cooperation of Miguel Arévalo, Manuel Valenzuela, Gabriela Palomino, Adriana Paredes, Carlos Maldonado, Carmen Galindo, Nancy Herrera, Moises Cab and the student members of the "Programa Camarón" (Unidad Académica SisalUNAM). Thanks are due to Selene Abad (Histopathology Laboratory, CIAD, A.C.Mazatlan) for training in histological analysis. The authors are highly indebted to

Dr D. Saulnier and A. Santini for their help in interpreting part of the phylogenetic tree. Thanks to Ann Grant for language correction and edition suggestions.

\section{References}

AQUACOP. 1984 Review of ten years of experimental penaeid shrimp culture in Tahiti and New Caledonia (South Pacific).J. World Maricult. Soc. 14: 7391.

Avnimelech, Y. 2012. Bio»FLOC» Technology-a practical guide book, $2^{\text {nd }}$ Edition. The World Aquaculture Society, Baton Rouge, Louisiana, United States.

Bairagi, A., Ghosh K.S., Sen, S.K., Ray, A.K. 2002. Enzyme producing bacterial flora isolated from fish digestive tracts. Aquaculture International 10(2), 109-121.

Ballester, E.L.C., Abreu, P.C., Cavalli, R.O., Emerenciano, M., De Abrew, L., Wasielesky Jr., W. 2010. Effect of practical diets with different protein levels on the performance of Farfantepenaeus paulensis juveniles nursed 
in zero water exchange suspended microbial FLOCs intensive system. Aquaculture Nutrition 16, 163-172.

Bianchi, M.A.G. 1979. Polyphasic study of the microbial ecology of bacteriaphytoplankton interactions. Presented at: Aquatic Microbial Ecology: Proceedings of the conference / sponsored by the American Society of Microbiology, 7-10 Feb 1979, Clearwater Beach, FL (USA).

Burford, M.A., Sellars, M.J., Arnold, S.J., Keys, S.J., Crocos, P.J., Preston, N.P. 2004. Contribution of the natural biota associated with substrates to the nutritional requirements of the post-larval shrimp, Penaeus esculentus (Haswell), in high-density rearing systems. Aquaculture Research 35, 508515.

Castex, M., Liet, C., Dominique, P., Pierrette, L., Nelly, W., Jean-Louis, N., et al. 2008. Probiotic $P$. acidilactici application in shrimp Litopenaeus stylirostris culture subject to vibriosis in New Caledonia. Aquaculture 275, 182-193.

Chun, J., Lee, J.H., Jung, Y., Kim, M., Kim, S., Kim, B.K., Lim, Y.W. 2007. EzTaxon: a web-based tool for the identification of prokaryotes based on $16 S$ ribosomal RNA gene sequences. International Journal of Systematic and Evolutionary Microbiology 57, 2259-2261.

Crab, R. 2010. Bio»FLOC»s technology: an integrated system for the removal of nutrients and simultaneous production of feed in aquaculture. PhD thesis, Ghent University. 178 pp.

Decamp, O., Conquest, L., Forster, I., Tacon, A.G.J. 2002. The nutrition and feeding of marine shrimp within zero-water exchange aquaculture production system: role of Eukaryotic microorganisms. In: Microbial Approaches to Aquatic Nutrition within Environmentally Sound Aquaculture 
Production Systems, (Ed. by C.S. Lee and P. O'Bryen), pp.79-86. World Aquaculture Society, Baton Rouge, FL, USA.

Defoirdt, T., Halet, D., Vervaeren, H., Boon, N., Van de Wiele, T., Sorgeloos, P., Bossier, P., Verstraete, W. 2007. The bacterial storage compound poly- $\beta$ hydroxybutyrate protects Artemia franciscana from pathogenic Vibrio campbelli. Environmental Microbiology 9(2), 445-452.

Dinh, T.N., Wille, M., De Schryver, P., Defoirdt, T., Bossier, P., Sorgeloos, P. 2010. The effect of poly- $\beta$-hydroxybutyrate on larviculture of the giant freshwater prawn (Macrobrachium rosenbergii). Aquaculture 302, 76-81.

Emerenciano, M., Cuzon, G., Arévalo, M., Mascaró-Miquelajauregui, M., Gaxiola, G. 2013. Effect of short-term fresh food supplementation on reproductive performance, biochemical composition, and fatty acid profile of Litopenaeus vannamei (Boone) reared under bio»FLOC» conditions. Aquaculture International

Far, HZ., Saad, CRB., Daud, HM., Kamarudin, Ramezani-Fard, E. 2013.Isolation and identification of bacteria microflora of white shrimp, Litopenaeus vannamei, with Antagonistic Properties Against Vibrio Species Asian Journal of Animal and Veterinary. Advances 8, 293-300.

Goarant, C., Merien, F. 2006. Quantification of Vibrio penaecida, the etiological of Syndrome 93 in New Caledonia shrimp by real-time PCR using SYBER Green I chemistry. Journal of Microbiological Methods 67, 27-35.

Griffith, D.R.W. 1995. Microbiology and the role of probiotics in Ecuadorian shrimp hatcheries. In: Larvi'95-Fish \& Shellfish Larviculture Symposium. In: 
Lavens, P., Jarpers, E., Roelants, I. (Eds.), European Aquaculture Society, Special Publication 24, Gent, Belgium, p. 478.

Halet, D., Defoirdt, T., Van Damme, P., Vervaeren, H., Forrez, I., Van de Wiele, T., Boon, N., Sorgeloos, P., Bossier, P., Verstraete, W. 2007. Poly- $\beta-$ hydroxybutyrate-accumulating bacteria protect gnobiotic Artemia franciscana from pathogenic Vibrio campbelli. FEMS Microbiology Ecology 60, 363-369.

Hsieh, S.L., Ruan, Y.H., Li, Y.C., Hsieh, P.S., Hu, C.H., Kuo, C.M. 2007. Immune and physiological responses in Pacific white shrimp (Penaeus vannamei) to Vibrio alginolyticus. Aquaculture $275,335-341$.

Palanisamy I., Thirumalai M, Ramasamy R, Santhiyagu P, Chandrasekaran K, et al. 2013. Aquatic Optimization of bacteriocin production by Lactobacillus sp. MSU3IR against shrimp bacterial pathogens. Biosystems 9, 12.

Izquierdo, M., Foster, I., Divakaran, S., Conquest, L., Decamp, O., Tacon, A. 2006. Effect of green and clear water and lipid source on survival, growth and biochemical composition of Pacific white shrimp Litopenaeus vannamei. Aquaculture Nutrition 12(3), 192-202.

Kumar, A., Singh, T.R. 2013. A quantitative study of gene regulatory pathways in Bacillus subtilis for virulence and competence phenotype by quorum sensing. Systems and Synthetic Biology 7, 33-39.

Lightner, D.V. (ed.). 1996. A handbook of shrimp pathology and diagnostic procedures for diseases of cultured penaeid shrimp. World Aquaculture Society, Baton Rouge, LA, USA.

Luis-Villasenor, IE., Castellanos-Cervantes, T., Gomez-Gil, B., Carrillo-Garcia, AE., Campa-Cordova, A. et al. 2013. Probiotics in the intestinal tract of 
juvenile whiteleg shrimp Litopenaeus vannamei: modulation of the bacterial community. World Journal of Microbiology \& Biotechnology 29, 257-265.

Ma, C W., Cho, Y S. and Oh, KH. 2009 Removal of pathogenic bacteria and nitrogens by Lactobacillus spp. JK-8 and JK-11 Aquaculture 287: 266-270.

Moriarty, DJ.W. 1999. Disease control in shrimp aquaculture with probiotic bacteria. In: Proceedings of the 8th International Symposium on Microbial Ecology. Bell C.R., Brylinsky M. and Johnson-Green P. (Eds.), Atlantic Canada Society for Microbial Ecology. Halifax, Canada.

Moss, S.M., LeaMaster, B.R., Sweeney, J.N. 2000. Relative abundance and species composition of gram-negative, aerobic bacteria associated with the gut of juvenile white shrimp Litopenaeus vannamei reared in oligotrophic well water and eutrophic pond water. Journal of the World Aquaculture Society 31(2), 255-263.

Nhan, D.T., Wille, M., De Schryver, P., Defoirdt, T., Bossier, P., Sorgeloos, P. 2010. The effect of poly $\beta$-hydroxybutyrate on larviculture of the giant freshwater prawn Macrobrachium rosenbergii. Aquaculture 302, 76-81.

Panjaitan, P. 2010. Shrimp culture of Penaeus monodon with zero water exchange model (Zwem) using molasses. Journal of Coastal Development 14(1), 3544.

Ray, A.J., Seaborn, G., Leffler, J.W., Wilde, S.B., Lawson, A., Browdy, C.L. 2010. Characterization of microbial communities in minimal-exchange, intensive aquaculture systems and the effects of suspended solids management. Aquaculture 310, 130-138. 
Sapcharoen, P. and Rengpipat, S. 2013. Effects of the probiotic Bacillus subtilis (BP11 and BS11) on the growth and survival of Pacific white shrimp, Litopenaeus vannamei Aquaculture Nutrition 19, 946-954.

Saulnier, D.S., Avarre, J.C., Le Moullac, G., Ansquer, D., Levy, P., Vonau, V. 2000. Rapid and sensitive PCR detection of Vibrio penaeicida, the putative etiological agent of Syndrome 93 in New Caledonia. Diseases of Aquatic Organisms 40, 109-115.

Schneider, O., Sereti, V., Eding, E.H., Verreth, J.A.A. 2006. Molasses as C sources for heterotrophic bacteria production on solid fish waste. Aquaculture 261, 1239-1248.

Soto-Rodríguez, S.A., Gómez-Gil, B., Lozano, R. 2010. "Bright-red" syndrome in Pacific white shrimp Litopenaeus vannamei is caused by Vibrio harveyi. Diseases of Aquatic Organisms 92, 11-19.

Supamattaya, K., Viriyapongsutee, B., Ruangsri, J., Encarnacao, P., Schatzmayr, G. 2005. Effect of probiotic Enterococcus faecium and phycophytic substances on growth performance and health condition of white shrimp (Penaeus vannameI). In: Mayer. E. (Ed.), Evaluation of Vibrio control with a multi-species probiotic in shrimp aquaculture.

Thompson, F.L., Abreu, P.C., Cavalli, R. 1999. The use of microorganisms as food source for Penaeus paulensis larvae. Aquaculture 174, 139-153.

Valdes, CEM., Macias, EB., Alvarez-Gonzalez, CA., Hernandez, CT., Sanchez, AJ. Efecto de microorganismos con potencial probiotico en la calidad del agua y el crecimiento de camaron Litopenaeus vannamei 
(Decapoda:Penaeidae) en cultivo intensivo 2013. Revista de Biologia Tropical 61, 1215-1228.

Vine, N.G., Leukes, W.D., Kaiser, H. 2006. Probiotics in marine larviculture. FEMS Microbiology Reviews 30, 404-427. 


\section{List of Tables}

Table 1. Values of physicochemical parameters obtained in clear water $(\mathrm{CW})$ and the FLOC.

Table 2. Average \pm SD for initial and final weight, DGC and survival rate in shrimp raised in clear water (CW) or FLOC.

Table 3. Histological findings of the hepatopancreas of juveniles of $L$. vannamei reared in clear water (CW) and Bio FLOC system indicating degree of lesions and occurrence. 
Table 1.

\begin{tabular}{lcccc}
\hline & CW & FLOC & CW & FLOC \\
\hline UPS & $36.6 \pm 0.5$ & $36.8 \pm 0.3$ & $37.2 \pm .8$ & $40.6 \pm 1.4$ \\
$\mathrm{~T}^{\circ} \mathrm{C}$ & $26.4 \pm 1.8$ & $26.5 \pm 0.6$ & $27.2 \pm 1.1$ & $28.0 \pm 1.1$ \\
$\mathrm{DO} \mathrm{mg} \mathrm{L}$ & $5.1 \pm 0.4$ & $4.4 \pm 0.2$ & $5.4 \pm 0.4$ & $4.8 \pm 0.2$ \\
$\mathrm{pH}$ & $7.7 \pm 0.2$ & $7.9 \pm 0.1$ & $7.5 \pm 0.2$ & $7.9 \pm 0.2$ \\
$\mathrm{~N}-\mathrm{NH}_{3} \mathrm{mgL}^{-1}$ & 0.6 & 0.6 & 0.6 & 0.6 \\
$\mathrm{~N}-\mathrm{NO}_{2} \mathrm{mg} \mathrm{L}^{-1}$ & 0.2 & 0.2 & 0.2 & 0.2 \\
$\mathrm{~N}-\mathrm{NO}_{3} \mathrm{mg} \mathrm{L}^{-1}$ & 10 & 10 & 10 & 10 \\
$\mathrm{FLOC}$ volume & - & 6.7 & - & 7.3 \\
$\mathrm{ml} \mathrm{L}^{-1}$ & & & &
\end{tabular}


Table 2.

\begin{tabular}{lllll}
\hline & CW w $/$ & CW w /o & FLOC w / & FLOC w /o \\
IWT & $4.76 \pm 0.20$ & $4.77 \pm 0.28$ & $4.67 \pm 0.15$ & $4.88 \pm 0.26$ \\
FWT & $6.69 \pm 1.05^{\mathrm{b}}$ & $7.25 \pm 0.85^{\mathrm{b}}$ & $12.54 \pm 0.31^{\mathrm{a}}$ & $12.41 \pm 0.66^{\mathrm{a}}$ \\
DGR mg d & $0.44^{\mathrm{b}}$ & $0.55^{\mathrm{b}}$ & $1.42^{\mathrm{a}}$ & $1.35^{\mathrm{a}}$ \\
survival(\%) & $71 \pm 17^{\mathrm{b}^{*}}$ & $54 \pm 15^{\mathrm{b}^{\star \star}}$ & $92 \pm 8^{\mathrm{a}^{*}}$ & $77 \pm 7^{\mathrm{a}^{* *}}$ \\
\hline
\end{tabular}

Superscripts indicate significant differences between treatments. Letters indicate significant differences due to the rearing system (CW vs. FLOC). Asterisc indicate significant differences due to the probiotic presence ( $\mathrm{w} / \mathrm{or} \mathrm{w} / \mathrm{o}$ ): Tukey test with $\mathrm{p}<0.05$. 
Table 3.

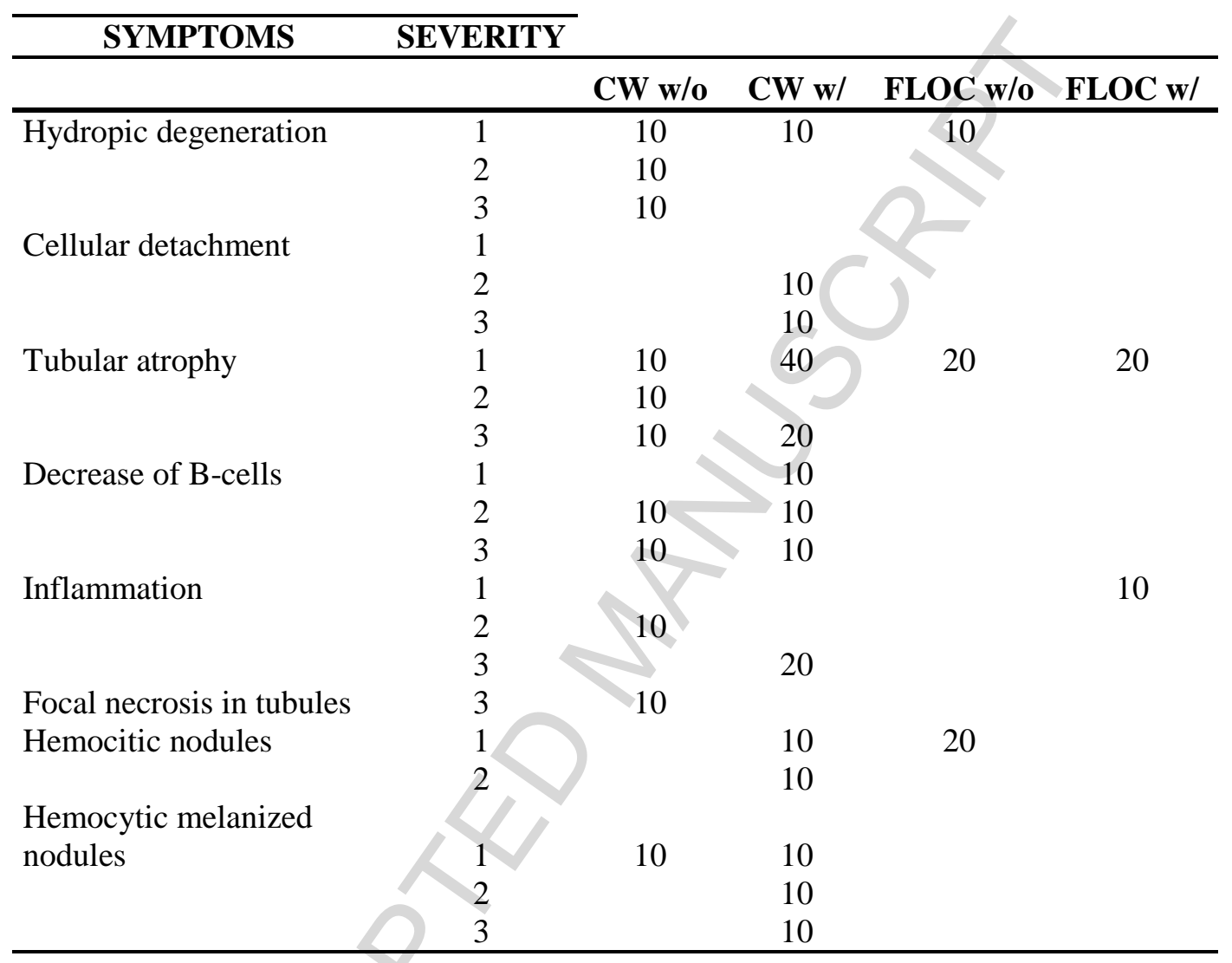




\section{Caption for Figures}

Fig 1: Phylogenic tree with Vibrio species present in CW and FLOC. Probiotic present (w/) or absent (w/o) in feed. V. rotiferianus, V. owensii, $\mathbf{}$ /. plantisponsor, V.vulnificus $\square$ strains in red possess $<98 \%$ identity with selected strains. Photobacterium phosphoreum was used as outgroup.

Fig 2. HP histology, shrimp raised in $\mathrm{CW}$ ( $\mathrm{w} /$ or w/o probiotic). (bar=50 $\mu \mathrm{m})$ except

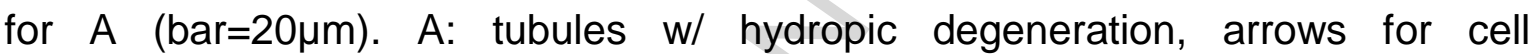
detachment. B: atrophied tubules $\mathrm{w} / \mathrm{a}$ decrease of B-cell; C: arrow for hemocytic nodules around tubules; $\mathrm{E}$ : tubule necrosis, arrow for melanization; $\mathrm{F}$ : inflammation, arrows for melanized nodules. (hematoxylin \& eosin staining). 


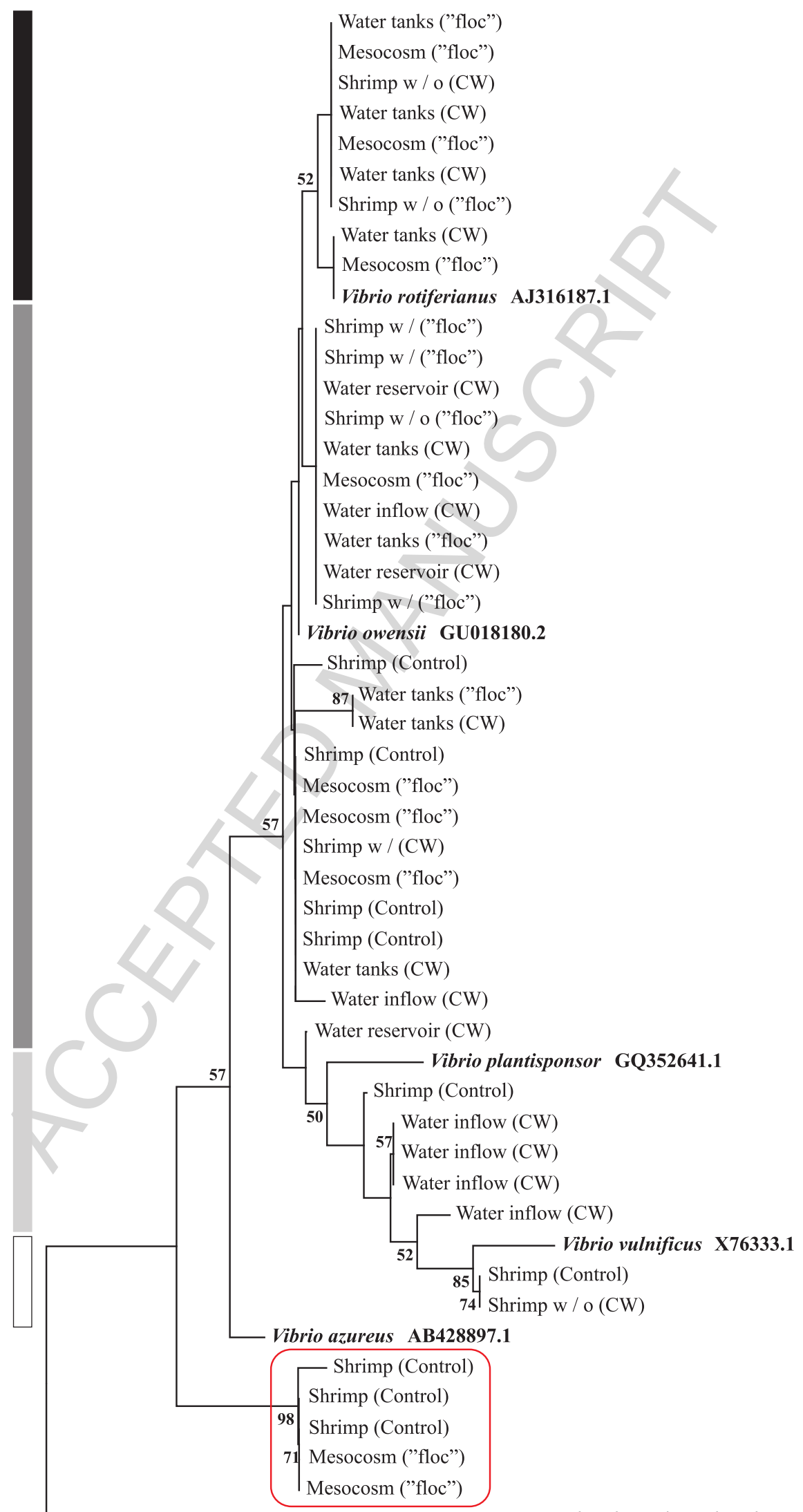

Photobacterium phosphoreum X74687.1

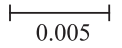

Fig 1: 


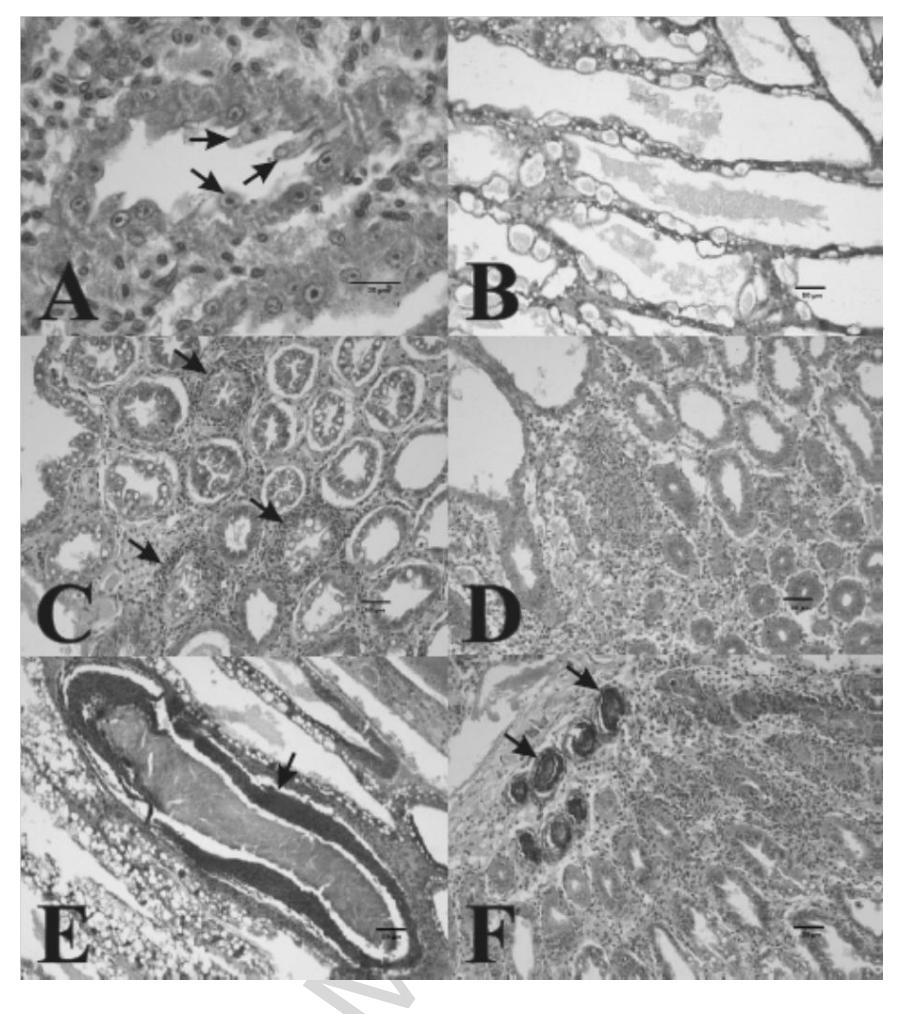

Fig 2.

Referees proposed: Avnimelech Yoram; Lightner Donald; Gatesoupe Joel; Gabaudan Jacques; Diaz Bruno 